\title{
GRAVE RELIEF OF SEMPRONIUS MARCELLINUS IN SAVARIA
}

\author{
TAMÁS GESZTELYI
}

\author{
Department of Classical Philology and Ancient History, University of Debrecen \\ Egyetem tér 1, H-4032 Debrecen, Hungary \\ E-mail: gesztelyi.tamas@arts.unideb.hu
}

\begin{abstract}
The grave relief of Sempronius Marcellinus in Savaria does not show the scene of abreptio Helenae - as thinks Z. Kádár - but rather the painful moment of Eriphyle's fateful decision followed by Amphiaraus's leave (profectio). The closest conceptual analogy of the scene can be found on the Phaedra-sarcophagus with the difference that the fateful decision is made by the man there, not by the woman. Instead of the multi-figure scene of the sarcophagi here the three-figure composition, together with the figures in the background, can compress the entire story, enabling a complex semantic interpretation. This meaning is fateful separation and praise of the deceased person. Sempronius Marcellinus, who had ordered the tombstone, placed himself in the role of Amphiaraus while his wife in that of Eriphyle. But the representation of their relationship is obviously not the expression of betrayal but of pain felt over eternal separation.
\end{abstract}

Keywords: Sempronius Marcellinus, Amphiaraus, Eriphyle, Phaedra, grave-symbolic

The literature has nothing but praise for the tombstone of Sempronius Marcellinus which was unearthed in the early $20^{\text {th }}$ century (Fig. 1). ${ }^{1}$ According to István Paulovics, "[it is] the most beautiful document of the Italian influence which, through the mediation of Savaria itself, flooded the mid-Danubian provinces via Aquileia, with its mythological scenes and mature decorative motifs". ${ }^{2}$ Zoltán Kádár argues that it is "one of the most beautiful and most important pieces, even by international standards, of the Museum of Szombathely". ${ }^{3}$ Terézia Buócz claims: "The culture of the bourgeoisie of Savaria, with its distinct Italian colour, fully prospered in the first half of the $2^{\text {nd }}$ century. An eloquent testimony to this is the most beautiful gravestone of the lapidarium which was unearthed in the town's early, Northern cemetery". ${ }^{4}$ In the international literature Michaela Fuchs refers to it as „Grabstein ... hoher Qualität". ${ }^{5}$

The detailed description and analysis of the tombstone consisting of six fields was performed by Z. Kádár. ${ }^{6}$ He dedicated a separate study to the interpretation of the mythological scene. ${ }^{7}$ In his description, "in the middle, on a bench with a back sits an almost naked male figure... On his left stands a similar-looking youth. Both turn to the right, where there stands a female figure with her legs crossed. ...behind her the naked upper body of a figure... flatly carved figure..., behind her neck, the upper curve of her wing is easily discernible (the smaller wing feathers are more blurred). Both male figures extend their right arms towards the naked female figure with a chignon (they

\footnotetext{
${ }^{1}$ Epigraphic Database Heidelberg HD 009562, ubi erat lupa Nr. 3104 (Mus. Savaria). I here to wish to thank Ortolf Harl for allowing me to use his photographs.

${ }^{2}$ Paulovics 1943, 25

${ }^{3}$ KÁDÁR 1958, 18.

${ }^{4}$ Buócz 1994, 49, Nr. 76.
}

${ }^{5}$ FuCHS 2005, 70.

${ }^{6}$ KÁDÁr 1961, 249-252.

${ }^{7}$ KÁDÁR 1958, 18-24. Having been published in Hungarian only, and not even in a professional periodical, it remained unknown to the international literature. 


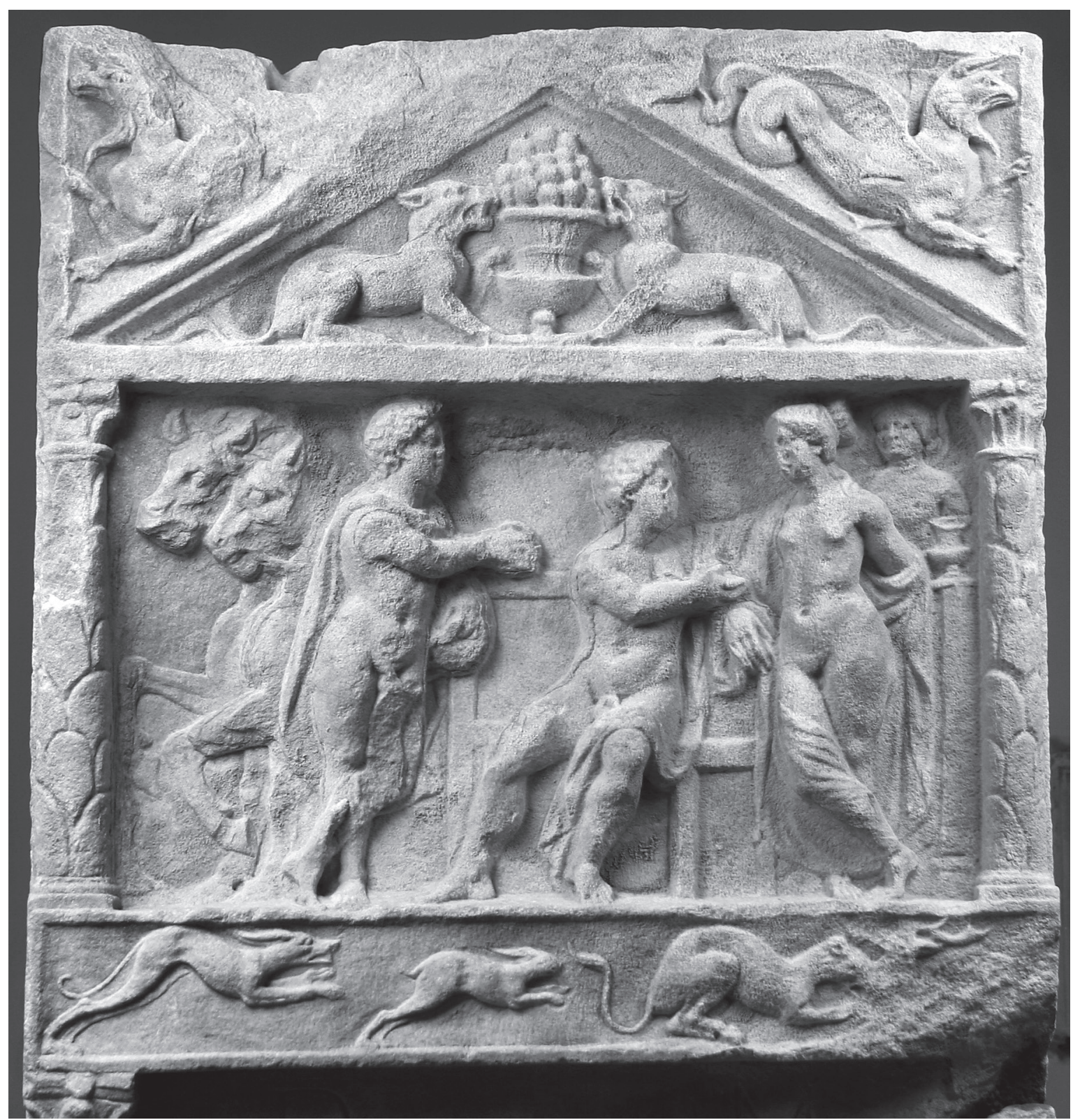

Fig. 1. Grave relief of Sempronius Marcellinus in Savariai: mythological scene (photo: Ortolf Harl)

may hold something in their hands, but that is not easy to discern), the seated man on the left even puts his left arm around her shoulder ... On the left..., behind the youths, the frontparts of the two horses looking left can be seen". ${ }^{8}$

Determining figures with no attributes has so far produced ideas rather than satisfying solutions. As early as the beginning of the $20^{\text {th }}$ century Carl Robert ${ }^{9}$ saw Tyro in the female figure with her husband, Cretheus, sitting in the middle, demanding an explanation over her twins begotten by Poseidon. The figure on the left leaning against the throne is supposed to be the shepherd who found and raised the abandoned infants, while the horses are references to the fact that the infants were fed with mare's milk. 
panion, and behind Helen, Amor, the trouble-maker. The horses on the left in the scene stomping their feet suggest Helen's abduction". ${ }^{24}$ The uncertainty of Kádár's interpretation is indicated not only by the expression "in all probability" but also by the fact that in the German language catalogue of the stone monument from Savaria published 13 years later he described this tombstone without mentioning the stroy. ${ }^{25}$

Certainly, some of Kádár's premises are questionable. He was the first to notice that there was a little winged figure behind the standing female figure who was none other than Amor. This led him to the following conclusion: "Who else among mortal women is more entitled to the sweet, mischievous child of Aphrodite, Goddess of Love than Helen, the Goddess's infamous favourite?!"26 To this we reply that a representation of Amor can be encountered in any mythological story that involves amorous relationships or feelings. Kádár's statement about the appearance of the standing female figure can be likewise questioned, "her light gesture, somewhat frivolous pose, the undisguised uncovering of her charms are all suggestive of the most favoured mortal protegee of the Goddess of beauty and love". ${ }^{27}$ It is true that both the female figure's posture and her nakedness can be called a Venus pose but it was in no way restricted to Helen. Maybe it suffices to mention a single counter-example from Pannonia: on a relief from Brigetio we can see Phaedra in an almost identical pose (Fig. 2). ${ }^{28}$ This relief is a good example of the occurrence of Amor, although the original story was about unrequited love only. The interpretation of the scene as the abduction of Helen lacks Paris's usual attribute, the Phrygian cap, as well as the usual means of the abduction, a ship. ${ }^{29}$ Despite all this, Kádár's interpretation was fully embraced by T. Buócz in her description of the lapidarium. ${ }^{30}$

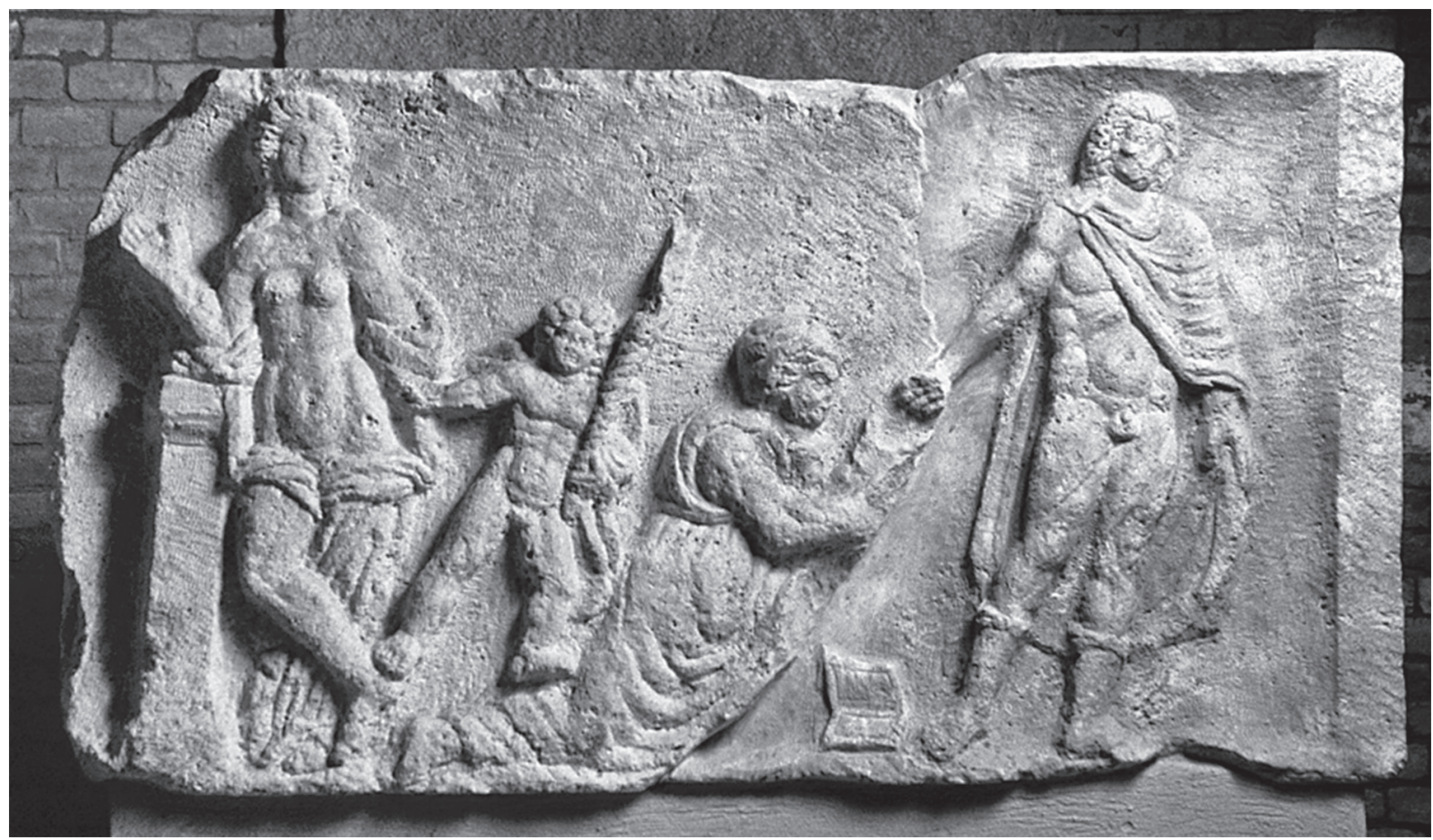

Fig. 2. Scene of Hippolytus and Phaedra on a relief from Brigetio (photo: Ortolf Harl)

${ }^{24}$ KÁDÁR 1958, 22-23.

${ }^{25}$ Steindenkmäler 1971, 106, Nr. 116.

${ }^{26}$ KÁDÁR 1958, 21.

${ }^{27}$ KÁDÁr 1958, 22

${ }^{28}$ ERdÉlyi 1966, 215, ubi erat lupa Nr. 3848 (Mus. Komárno). The more recent catalogues prepared for the lapidarium (HARL-LôRINCZ 2002, 12 Kat. 4; BorHy 2006, 59 Kat. 26) regard the female figure appearing in Venus' pose as Venus herself, however, this interpretation does not fit the scene in any way. Paradoxically, the former catalogue provides the following explanation for this: "Behind the nurse stands the invisible goddess of love, leaning on her altar, accompanied by her son Eros. It was the goddess that aroused forbidden passion in Phaedra for her stepson, which proved to be fateful." ${ }^{29}$ WOHLMAYR 2008, 1164ff.

${ }^{30}$ Buócz 1994, 49 Nr. 76. 
More recent attempts at determination came to light only 50 years later, in the early $21^{\text {st }}$ century. Michaela Fuchs looks for iconographic analogies of the scene in $4^{\text {th }}$ century B.C. vase paintings, where the attributes and the occasional inscriptions also help the interpretation of the figures..$^{31}$ Based on those, the male figure on the throne and the one standing next to him may be the Dioscuri but equally likely Theseus and Pirithous, too, and the standing female figure may be Helen. In Fuchs' final analysis, the relief from Savaria describes the abduction of Helen committed by the two friends Theseus and Pirithous and in the background their horses are shown. This solution akin to Paulovics's interpretation came to light without Fuchs knowing about Paulovics's work. The interpretation of the female figure as Helen is eventually linked to the sepulchral concept of the abduction (abreptio) as first stressed by Z. Kádár.

Wolfgang Wohlmayr also dedicated an entire study to the issue of interpretation which he closes with the following words: the complex apparatus of Roman gravestone symbolism unfolds on it whose exact meaning should remain obscure. (,An ihr entfaltet sich ein vielfältiger Apparat römischer Grabsymbolik und ineinander greifender Motive, deren genaue Bedeutung uns versagt bleiben muss." ${ }^{32}$ From this it follows that he simply considers options some of which he himself finds debatable. For instance, the story of Tyro could be involved in the interpretation as a meeting between the mother and her twins. However, when this story was portrayed, this scene usually took place either by a well or at Hera's shrine, of which there is no sign here whatsoever. ${ }^{33}$

Wohlmayr mentions a scene from a wall painting from Herculaneum as a further option. Achilles sits on a chair with a back, Patroclus leans against the chair's back - like the youths on the tombstone of Sempronius -, and on the left, there is a horse. ${ }^{34}$ According to this, the female figure of the tombstone would be Briseis either during a farewell or returning. This, however, we can oppose by saying that in the case of a slave woman an intimate gesture involving leaning on the arm of the chair and the seated man putting his arm around her shoulder is not conceivable. Nor would Amor's presence be justifiable, since there is no amorous relationship between the two figures.

Endre Tóth, ${ }^{35}$ who has prepared the most recent catalogues of the Savaria Museum's lapidarium, must have found none of the existing interpretations satisfying for he adhered to the desrciption of the figures without names.

From our part, we start with the assumption that it is the seated male and the standing female figures that belong together, indicated by the male's embracing gesture and the presence of Amor in the background. The male figure leaning against the throne is more loosely linked to the composition. We think that the interpretation of the female figure as Eriphyle suggested by G. Erdélyi is a workable option as long as we do not look for the motif of bribery in the scene but rather that of decision. Amphiaraus, Eriphyle's husband, had sworn to Adrastus following a feud that in their next dispute he would let Eriphyle decide and he would accept that decision whatever it might be. ${ }^{36}$ This soon happened in the issue of the campaign to be launched against Theba, initiated by Adrastus with a view to restoring Polyneikes's power. However, Amphiaraus not only opposed this idea but also refrained from participating in it because, due to his foresight, he foresaw both the failure of the siege and his own doom. This is why they both turned to Eriphyle for a decision, who had by that time been bribed by Polyneikes with a necklace from Harmonia to make Amphiaraus decide for participation in the campaign.

Sempronius Marcellinus's grave relief depicts this fateful event. In the middle sits Amphiaraus, putting one hand on his wife's shoulder, and raising the other towards her beseechingly or askingly. Their marital relationship and Amphiaraus' devoted love are expressed by Amor's presence in the background. The male figure standing on the left is Adrastus, who also raises his right hand in an expecting gesture. Both men turn intensely towards Eriphyle, waiting to hear her decision. The horses on the left of the scene suggest the outcome of the decision: Amphiaraus has to leave for the campaign against Theba. The scene is unique, it has no analogies. However, there is an important element: the motif of the team of horses has an emphatic role in the iconography of the representations of Amphiaraus: either this is how he leaves home or he perishes together with them, swallowed by the abyss of the opening Earth. ${ }^{37}$ The main character of the scene is thus Amphiaraus sitting in the centre, it is his fate that is going to be decided by the answer that both men expect from Eriphyle, as reflected in their gestures.

\footnotetext{
${ }^{31}$ FUCHS 2005, 70-77.

${ }^{32}$ WOHLMAYR 2008, 1167

${ }^{33}$ WOHLMAYR 2008, 1163 f.

${ }^{34}$ WOHLMAYR 2008, 1165.
}

\author{
${ }^{35}$ То́тн 2011, 168 Nr. 117. \\ ${ }^{36}$ Apollodorus III 6, 2; in detail see BETHE 1894, col. \\ $1889-1890$ \\ ${ }^{37}$ Krauskopf 1981, Nr. 7-21, ill. Nr. 40-46.
}


But what is this story doing on a grave relief? It is difficult to imagine that it served to immortalize the betrayal of a spouse. The scenes of imperial sarcophagi suggest that mythical love stories undergo a change of meaning. Examples of this are the stories of Ariadne and Phaedra. ${ }^{38}$ The former turned into the paradigm of being cheated and the latter that of rejection in the literary works of Antiquity. Both interpretations seem absurd depicted on tombstones. They were replaced by the paradigm of unconditional love, which, however, was broken by final separation. Thus the motif of rejected or cheated love softened to a farewell scene. The relief on the sarcophagi depicting Phaedra's story included an additional scene. Hippolytus leaves for a boar-hunt. Here it becomes clear that the original story took on new meanings. Hippolytus is not rushing to his own destruction, like in the original story, but, with his hunting, he reveals his manly bravery and virtue. A similar motif can be discovered in the use of Ariadne's story as well. Next to Ariadne lying on the ground, at the feet of Theseus, lies the defetated Minotaurus. This scene, then, unites painful farewell and praise for the virtue of the deceased person. What is more, the latter sarcophagus was not even prepared for a spouse but for a deceased child, as proved by the inscription and the portraits. The child is Theseus, while in the figure of Ariadne the abandoned mother appears. ${ }^{39}$ This further confirms the re-interpretation: it is not unfaithfulness but death that separates us from each other, although the surviving party may experience this as deception, cheating or abandonment.

As I mentioned before, one among the above topics from sarcophagi, the story of Hippolytus is also known from a relief of a funerary monument from Brigetio (Fig. 2). ${ }^{40}$ There the story is condensed into a single scene, that of rejection and separation. The two main characters' hand gestures can be regarded as a gesture of farewell: Phaedra raises her right hand while Hippolytus extends his to the right. Only Phaedra's lower body is covered by a cloak so her female beauty can reveal itself, as can be seen in the figure of Eriphyle on the relief from Savaria. Amor takes an active role here: in his left hand he holds a wedding torch and with his right hand he appears to pull Phaedra towards Hippolytus. At any rate, Amor's figure can be interpreted as none other than the expression of mutual love between the spouses on either this relief or on the one from Savaria. Eriphyle does not vilely cheat her love but rather she sends her spouse off on his way, at the mercy of fate. The team of horses in the background even offers an opportunity to evoke Amphiaraus' virtue since this is what takes him to battle, where he fights bravely until he is killed. And then, as Apollodorus writes - "Zeus made him immortal". ${ }^{41}$ In this way the figures in the background in the three-figure composition also take on an emphatic role.

We are lucky enough to have at our disposal not only the tombstone but the complete inscription of its relief, enabling us to examine the interrelationship between the two (Fig. 3). There are six names in the inscription: a couple, C. Sempronius Marcellinus and Claudia Spectata, their two children: Sempronius Marcellianus and Sempronius Marcellus, and the two brothers of the father: Sempronius Passer and Sempronius Florentinus. However, age is specified only in the case of the two boys and one of the brothers - no age is specified for the rest of the names, there are only blank spaces there. If our point of origin were the deceased persons, then we would not find an explanation for the painful separation of the spouses. The inscription, however, reveals that the tombstone was erected by the father while alive so he himself could choose the representation. At that time he must have thought that he was erecting the tombstone for himself and his wife, expressing the painful separation of the two of them on the relief. He did not forget, either, to represent his personal virtue in the mythical scene. However, life overthrew his plans because his two sons and his younger brother died earlier than him. That was why he had to condense their names in the bottom part of the inscription with smaller letters and ligatures. In the end, the husband and wife probably were not even buried in this tomb since no ages were added to their names later, either.

In sum we can conclude that the grave relief of Sempronius Marcellinus does not show the scene of abreptio Helenae but rather the painful moment of Eriphyle's fateful decision followed by Amphiaraus's leave (profectio). The closest conceptual analogy of the scene can be found on the Phaedra-sarcophagus with the difference that the fateful decision is made by the man there, not by the woman. Instead of the multi-figure scene of the sarcophagi here the three-figure composition, together with the figures in the background, can compress the entire story, enabling a complex semantic interpretation. This meaning is fateful separation and praise of the deceased person.

${ }^{38}$ ZANKER-Ewald 2004, 45ff., 54ff.
${ }^{39}$ ZANKER-EwaLd 2004, 379: „D Daß Ariadne im Mythos
die Geliebte des Theseus ist und nicht dessen Mutter, schien zweitran- gig unter dem Aspekt von Liebe und Abschiedschmerz den die Identifizierung mit den mythischen Figuren ausdrücken soll."

${ }^{40}$ ERdÉLYI 1966, 211-223.

${ }^{41}$ Apollodorus III 6, 2. 


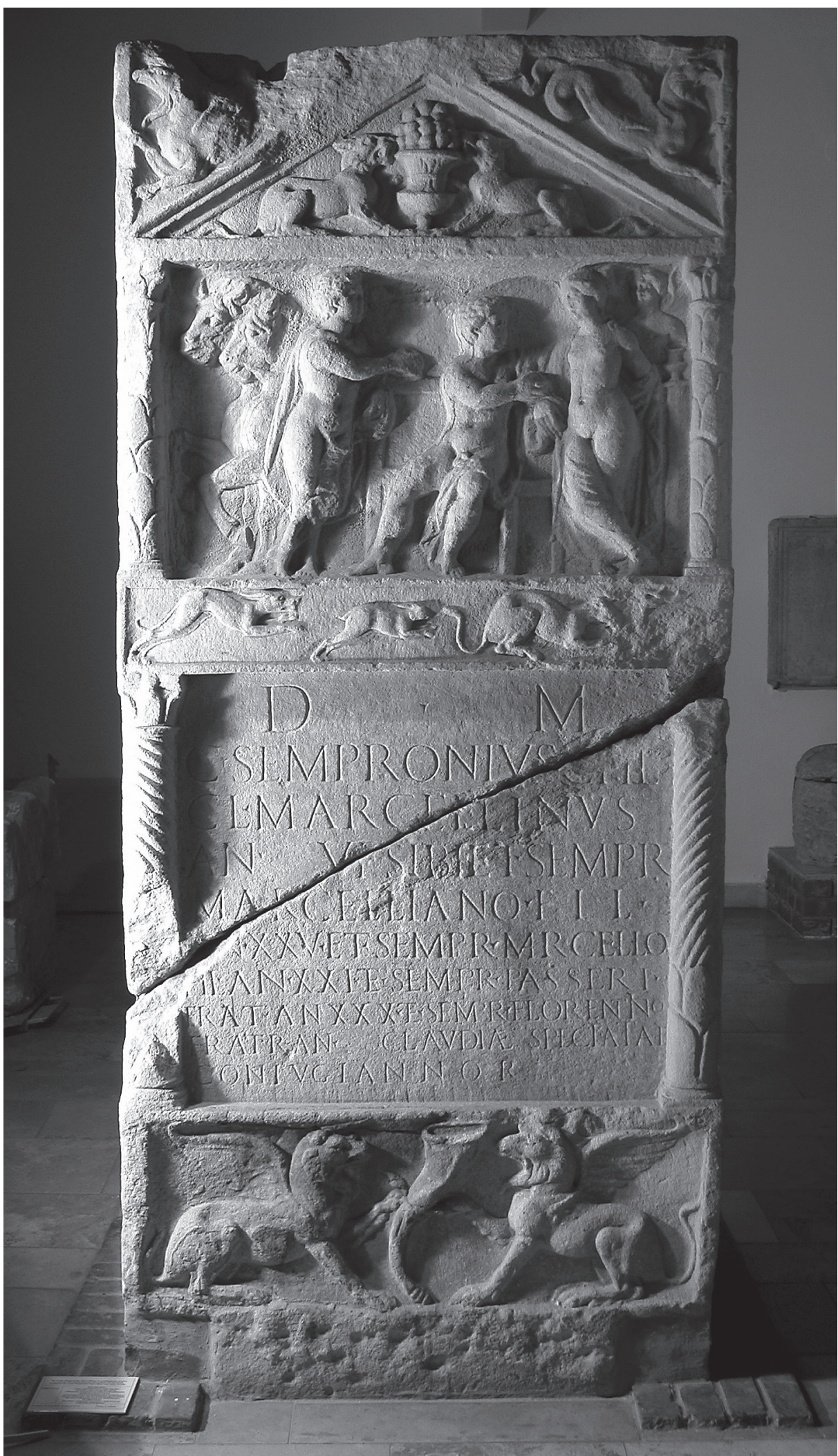

Fig. 3. Tombstone of Sempronius Marcellinus in Savaria (photo: Savaria Múzeum, Szombathely) 
Sempronius Marcellinus, who had ordered the tombstone, placed himself in the role of Amphiaraus while his wife in that of Eriphyle. But the representation of their relationship is obviously not the expression of betrayal but of pain felt over eternal separation.

\section{ABBREVIATIONS}

BETHE 1894

BORHY 2006

Buócz 1994

ERDÉLYI 1950

ERDÉLYI 1966

ERDÉLYI 1974

ERTEL 2010

FuCHS 2005

HARL-LŐRINCZ 2002

KÁDÁR 1958

KÁDÁR 1961

KRAUSKOPF 1981

Lezzi-Hafter 1986

Paulovics 1943

PREISENDANZ 1916-1924

RADKE 1948

ROBERT 1916

SCHOBER 1923

SIMON 1997

Steindenkmäler 1971

TóTH 2011

WOHLMAYR 2008

ZANKER-EWALD 2004
= E. BETHE: Amphiaraos. RE I. Stuttgart 1894, col. 1886-1893.

= L. BorHY: Vezető Komárom város római kori kőemlékeihez (Guide to the Roman Stone Monuments of the City of Komárom). Acta archaeologica Brigetionensia Ser.I. 5. Komárom 2006.

= T. Buócz: Lapidarium Savaria Múzeum (Das Lapidarium des Savaria Museums). Szombathely 1994.

= G. ERDÉLYI: Roman grave plates in Pannonia with mythological scenes (Stéles romains Pannoniens ornés de scénes mythologiques). ArchÉrt 77 (1950) 72-84.

= G. ERdÉlyI: A Hippolytus relief from Szőny. ActaAntHung 14 (1966) 211-223.

= G. ERDÉLYI: A római kőfaragás és kőszobrászat Magyarországon (Roman Stone Carving and Stone Sculpture in Hungary). Apollo könyvtár 5. Budapest 1974.

= CH. ERTEL: Bestandteile von römischen Grabbauten aus Aquincum und dem Limesabschnitt im Stadtgebiet von Budapest. CSIR Ungarn 9. Budapest 2010.

= M. Fuchs: Der Grabstein der Sempronier in Savaria: Neues zu Reflexen klassischer Malerei in Noricum. In: G. Grabherr-B. Kainrath -A. Larcher-B. Welte (Hrsg.): Vis imaginum. Festschrift für Elisabeth Walde zum 65. Geburtstag. Innsbruck 2005, 70-77.

= F. HARL-B. LŐRINCZ: A római kőtár vezetője a komáromi erődrendszer VI. bástyájában [Guide of the Roman Lapidarium in the $6^{\text {th }}$ Bastion of the Komarom Fortress System]. Komárno-Wien 2002.

= Z. KÁDÁR: Szép Heléna története egy szombathelyi sírkövön (Die Geschichte der schönen Helena auf einem Grabmal von Szombathely). Vasi Szemle 1 (1958) 18-24.

= Z. KÁDÁR: C. Sempronius Marcellinus savariai sírköve (Der Grabstein von C. Sempronius Marcellinus in Savaria). ArchÉrt 88 (1961) 249-252.

= J. KRAUSKOPF: Amphiaraos. LIMC I. Zürich-München 1981, 691-713.

= A. Lezzi-Hafter: Eriphyle. LIMC III. Zürich-München 1986, 843-846.

= I. PAUlovics: Lapidarium Savariense. Római kőemlékek új felállítása a Szombathelyi Múzeumban [Lapidarium Savariense. New establishment of Roman stone monuments in the Savarian Museum]. Acta Savariensia 2. Szombathely 1943.

= K. Preisendanz: Tyro. Ausführliches Lexikon der griechisch-römischen Mythologie 5. Hrsg. W. H. Roscher. Leipzig 1916-1924.

= G. RADKE: Tyro. Realencyclopädie des klassischen Altertumswissenschaft. VII.A. Hrsg. von A. F. Pauly, G. Wissowa, W. Kroll, K. Mittelhaus, K. Ziegler, W. John.. Stuttgart 1948, col. 1869-1875.

= C. ROBERT: Tyro. Hermes 51 (1916) 273-302.

= A. Schober: Die römischen Grabsteine von Noricum und Pannonien. Wien 1923.

= E. SIMON: Tyro. Lexikon Iconographicum Mythologiae Classicae VIII. Zürich-München 1997, 153-154.

= A. Mócsy-T. SzEnTLÉleKy (Hrsg.): Die römischen Steindenkmäler von Savaria. Budapest 1971.

= E. TóтH: Lapidarium Savariense. Roman stone monuments in Savaria, with inscriptions. Savaria 34/2. Szombathely 2011.

= W. Wohlmayr: Zur sog. Sempronier-Stele im 'Savaria Múzeum'. In: Ch. Franek-S. LammT. Neuhauser-B. Porod-K. Zöhrer (Hrsg.): Thiasos. Festschrift für Erwin Pochmarski zum 65. Geburtstag. Veröffentlichungen des Instituts für Archäologie der Karl-Franzens-Universität Graz 10. Wien 2008, 1161-1171.

= P. ZANKER-B. Chr. EwAld: Mit Mythen leben. Die Bilderwelt der römischen Sarkophage. München 2004. 